\title{
Biological Management of the Root-knot Nematode on Strawberry in Egypt
}

\author{
Hammam M.M.A., Wafaa M. A. El-Nagdi, H. Abd-El-Khair and \\ M. M. M. Abd-Elgawad \\ Plant Pathol. Dept., National Res. Centre, Tahrir St., Dokki 12622, Giza, Egypt. \\ Corresponding author email: mahfouzian2000@yahoo.com
}

\begin{abstract}
The effect of commercial biocontrol products viz. Nemakill, Nemaless, Micronema as well as an Egyptian entomopathogenic nematode (EPN) strain of Heterorhabditis bacteriophora-infective juveniles (IJs) within either cadavers of Galleria mellonella last instar larvae or EPN-IJs in water suspension, compared to chemical nematicides of Nema Plus Zero and Oxamyl on Meloidogyne incognita developmental parameters, strawberry growth and yield and rhizosphere microbial community were determined in two separated field experiments. Six months after strawberry transplanting, 30-88\% reduction in nematode juveniles $\left(\mathbf{J}_{2}\right)$ in soil was achieved by Nemakill, Nemaless and Micronema, while reduction range was $37-64 \%$ by EPNs compared to $64-73 \%$, by chemicals. The commercial products followed by EPNs significantly reduced the numbers of $M$. incognita- $\mathrm{J}_{2}$, galls, and egg masses in strawberry roots. All treatments enhanced strawberry growth and yield parameters. Nemakill followed by EPNs in water and within insect gave best fruit yield of strawberry cv. Festival. Nemaless followed by Nemakill and Micronema gave best fruit yield of strawberry cv. Fertona. Effect of tested treatments on rhizosphere microbial community and mycoflora frequency in treated strawberry plants was presented and discussed.
\end{abstract}

Key words: Biological control, entomopathogenic nematode, Meloidogyne, rhizosphere microbial community.

\section{INTRODUCTION}

Strawberry (Fragaria ananassa Duch.) is one of the most economically important crops worldwide. It is grown under a wide range of climatic conditions, where cultivated for producing small delicious fruits (Kurze et al., 2001). Strawberry is important as a source of macronutrients and beneficial dietary compounds (Bianco et al., 2009) with benefits on neurodegenerative and cardiovascular diseases (Bombarely et al., 2010). The root-knot nematodes, RKNs (Meloidogyne spp.) especially $M$. incognita in Egypt (Ibrahim, 1985), cause considerable losses in many economically important crops. It is highly pathogenic to staple crops such as maize, potato, soybean, banana, tomato, sweet potato and yam; and industrial crops such as tobacco, coffee, sugar cane, sugar beet, cotton and pepper. Often this species also causes economic damage to fruit crops such as guava, pineapple, papaya, grapes, and strawberry (e.g. Pinkerton and Finn, 2005; Perry et al., 2009). Meloidogyne incognita, $M$. javanica, $M$. arenaria and $M$. hapla are among the most economically important species of rootknot nematodes. Meloidogyne hapla has been observed in four major strawberry 
producing areas in Québec, Canada (Bélair and Khanizadeh, 1994). Dickstein and Krusberg (1978) classified 33 strawberry cultivars as susceptible and least susceptible to $M$. hapla infection under greenhouse conditions on the basis of a galling index on the root system. Edwards et al. (1985) and Szczygiel (1981) suggested such a rating to be misleading, because cultivars with moderate root galling showed no significant growth reduction and thus were identified as tolerant. Eleven strawberry varieties were screened for their resistance against $M$. incognita by Neelam and khan (2013) in micro plots infested fields; out of which Tiago and Torrey were found resistant but Chandler was highly resistant against root knot nematode.

Growing dissatisfaction with chemical nematicides due to their environmental and health hazards has created markets for bio-nematicide products worldwide. In this respect, Bacillus megaterium greatly reduced the numbers of galls, females and eggmasses of $M$. incognita in the roots of sugar beet, followed by Bacillus subtilis, Paecilomyces lilacinus, $P$. fumosoroseus and Trichoderma album in greenhouse and field experiments (El-Nagdi et al., 2011). The commercial products Stanes sting ( $B$. subtilis), Bio-Nematon (P. lilacinus), Stanes symbion vam plus (Glomus fasciculatum and Gigaspora sp.) and Rhizo-N (B. subtilis) reduced nematode parameters of M.arenaria on potato plants in the field. These treatments also increased the averages of growth and yield parameters (Abd-El-Khair and El-Nagdi, 2014). Bacillus methylotrophicus and Lysobacter antibioticus, when applied as soil drenches or seed treatments in greenhouse experiments, reduced root-knot severity and incidence of $M$. incognita on tomato compared to no-bacterium control. The treatments reduced rootknot disease levels and increased yields, compared to the untreated check in field trials (Zhou et al., 2016). Hammam et al. (2016) found that the two formulations of entomopathogenic nematodes (EPNs), Heterorhabditis bacteriophora-infective juveniles (IJs) within either cadavers of Galleria mellonella last instar larvae or IJs in water suspensions, Bio-Nematon, Stanes sting, Micronema, Nema Plus Zero and Carbofuran could control the citrus nematode, Tylenchulus semipenetrans, population levels in Mandarin orchard.

The present work aimed at studying the effect of commercial products of Nemakill, Nemaless, and Micronema, in addition to the above-mentioned two formulations of EPNs, compared to the chemical nematicides Nema Plus Zero and Oxamyl, on $M$. incognita developmental parameters, growth \& yield of strawberry and rhizosphere microbial community.

\section{MATERIALS AND METHODS}

\section{Experimental field:}

Two separate field experiments were conducted at Badr County, El Bahera Governorate, Egypt, during 2017-2018 season to test the antagonistic effects of selected biocontrol agents on $M$. incognita, rhizosphere microbial community, frequency of mycofolra and strawberry growth parameters and yield. Strawberry cultivars Festival and Fertona were separately transplanted on 20 and 11 September, 2017 in the two M. incognita-infected fields, respectively. Each field experiment, with loam sandy soil, consisted of 40 plots; each plot $(3 \times 1 \mathrm{~m})$ consisted of four plant rows. All tested treatments were applied as soil treatments. Five plots were used as replicates for each treatment as well as the untreated check. All agricultural practices were carried out as recommended (El-Shemy et al., 2013). 


\section{Treatments:}

On 30 October, 2017, eight treatments applied as soil drench in a randomized complete block design were as follows:

1. Nemakill ${ }^{\circledR}$ (natural oils) was applied at $85 \mathrm{ml} / 10 \mathrm{~L} /$ plot

2. Nemaless ${ }^{\circledR}$ (containing $10^{9}$ colony forming unit (CFU)/ml of Serratia marcescens was applied at $85 \mathrm{ml} / 10 \mathrm{~L} /$ plot

3. Micronema ${ }^{\circledR}$ (containing $10^{9} \mathrm{CFU} / \mathrm{ml}$ of Serratia sp., Pseudomonas sp., Azotobacter sp., Bacillus circulans and Bacillus thuringiensis) was applied at $170 \mathrm{ml} / 10 \mathrm{~L} / \mathrm{plot}$

4. An Egyptian entomopathogenic nematode strain of Heterorhabditis bacteriophora at rate of $100 \mathrm{ml}\left(125\right.$ of infective juveniles $\left./ \mathrm{cm}^{2}\right)$ on the soil surface under strawberry seedling.

5. H. bacteriophora-infected cadavers of Galleria mellonella last instar larvae was applied at a rate of 5 insect (Galleria mellonella) beneath soil surface under strawberry seedling.

6. Nema Plus Zero ${ }^{\circledR}$ (a.i. 2.4-dinydroxybenzene 12.5\%, 2.4-dichloropropene and inert ingredients $81.5 \%$ ) was applied at $25 \mathrm{~g} / 10 \mathrm{~L} /$ plot

7. Vydate ${ }^{\circledR} 24 \%$ L (Oxamyl) [N, N-dimethyl-2-methylcarbamoyloxyimino-2(methylthio) acetamide] was applied at $5 \mathrm{ml} / 1 \mathrm{~L} /$ plot.

8. Untreated control.

\section{Effect on M. incognita developmental parameters:}

Initial soil samples were taken from each field experiment before transplanting. Then, soil and root samples were taken two, four and six months after transplanting. Five 200-g-soil samples were taken from each plot at a depth of $15-30 \mathrm{~cm}$. Nematodes were extracted from soil by sieving and decanting method described by Barker (1985). The numbers of juveniles $\left(\mathrm{J}_{2}\right)$ of $M$. incognita in soil were counted using Hawksly slide under light microscope. Root samples were gently washed free of soil and an aliquot of $5 \mathrm{~g}$ per plot (5 plants) was cut into 2-cm-long pieces. At each sampling time, the root pieces were placed in Petri dishes with distilled water incubated under laboratory conditions $\left(25 \pm 5^{\circ} \mathrm{C}\right)$ for a week to extract and count $M$. incognita- $\mathrm{J}_{2}$. The numbers of nematode galls and egg masses were also counted in another $5 \mathrm{~g}$ root. The percentage reductions of the root-knot nematode populations in soil $\left(\mathrm{J}_{2}\right)$ induced by the treatments were determined according to the formula of Handerson and Tilton (Puntener, 1981):

$$
\text { Nematode reduction }(\%)=[1-(\mathrm{PTA} / \mathrm{PTB} \times \mathrm{PCB} / \mathrm{PCA})] \times 100
$$

Where PTA $=$ Population in the treated strawberry plant after application, $\mathrm{PTB}=$ Population in the treated strawberry plant before application, $\mathrm{PCB}=$ Population in the check strawberry plant before application and PCA $=$ Population in the check strawberry plant after application. 


\section{Effect on strawberry growth and yield parameters:}

Effect of tested treatments on plant growth and yield parameters was recorded. A random sample of ten strawberry plants was separately taken from each treatment as well as control six months after transplanting. The averages of shoot lengths $(\mathrm{cm})$, fresh \& dry weights of shoot, and root fresh weight $(\mathrm{g})$ were determined. So, the yield parameters was recorded as only one random harvest time of fruit yield $(\mathrm{kg})$ per plot, then divided by plant numbers/plot to get one harvest fruit yield $(\mathrm{g})$ per plant, and multiplied by number of collection times to obtain harvest fruit yield $(\mathrm{kg})$ per plotseason. Strawberry fruits were collected almost weekly for 16 weeks (16 harvest times).

\section{Effect on rhizosphere microbial counts:}

Effect of the tested treatments on total counts of aerobic bacteria; spore-forming bacteria and fungi at the rhizosphere soil of strawberry plants were determined by the plate count technique using dilution method on suitable media (Ghini et al., 2007). Ten grams of each soil sample were separately shaken in $90 \mathrm{ml}$ of sterilized distilled water in a $250 \mathrm{ml}$ flask, 20 minutes on a shaker, to give a dilution of $10^{-1}$. Then, serial dilutions up to $10^{-7}$ of fresh suspension was prepared, for each sample, by transferring $1 \mathrm{ml}$ of sample suspension to $9 \mathrm{ml}$ sterilized distilled water in a test tube under sterile conditions. Five replicated plates were prepared for each dilution per soil sample. To determine the aerobic bacterial count, Aliquots $1.0 \mathrm{ml}$ of $10^{-5}-10^{-7}$ dilution were transferred onto separated sterilized Petri plates filled with nutrient agar (NA) medium; Peptone 5 g, Beef extract 3 g, Agar 15 g, Distilled water 1L, pH 7 (Bridson, 1995). After 2 days of incubation at $30^{\circ} \mathrm{C} \pm 2$, the resulted aerobic bacteria are presented as a number of colony-forming units (CFU) per 10 gram of soil.

After pasteurization of dilution of $10^{-1}$ at $80{ }^{\circ} \mathrm{C}$ for $20 \mathrm{~min}$., the count of sporeforming bacteria was determined. Aliquots $1.0 \mathrm{ml}$ of $10^{-3}-10^{-5}$ dilutions were transferred onto separated sterilized Petri plates filled with NA for 2 days of incubation at $30 \pm 2{ }^{\circ} \mathrm{C}$ (Bridson, 1995). The resulted spore-forming bacteria were presented as CFU/10 g of dry soil. To count the fungi, aliquots $1.0 \mathrm{ml}$ of each $10^{-3}$ and $10-^{4}$ dilution were transferred onto separated sterilized Petri plates filled with Martin medium; Glucose 10g, Peptone 5g, $\mathrm{KH}_{2} \mathrm{PO}_{4} 1 \mathrm{~g}, \mathrm{MgSO}_{4} 0.5 \mathrm{~g}$, Rose Bengal 30 $\mu \mathrm{g}$, streptomycine 0.03g,Agar 15g, Distilled water 1L (Bridson, 1995). The inoculated plates were incubated at $30 \pm 2{ }^{\circ} \mathrm{C}$ for 7 days before count of the fungi.

\section{Effect on Mycoflora frequency:}

Effects of tested treatments on the percentages of fungi occurrence in the rhizosphere of strawberry was determined as CFU per 10 gram of soil on Martin medium by the pour plate method and dilution technique (Ghini et al., 2007). One gram of soil was suspended in $90 \mathrm{ml}$ sterile water to obtain a 1/100 dilution. Then, serial dilutions were prepared up to $10^{-5}$. Five replicated plates were prepared for each dilution per soil sample. The plates were incubated at $30^{\circ} \mathrm{C} \pm 2$ for 7 days. Fungi that grew out were count as $\mathrm{CFU} /$ plate. The resulted fungi were identified to genus and species level according to the key of morphological and cultural characters described by Ellis (1971) and Barnett \& Hunter (1972). Each isolated fungus was counted and its frequency percentage was calculated according to the following formula:

Frequency of common mycoflora $(\%)=$ (fungus no. / total fungi no.) $\mathrm{X} 100$ 


\section{Statistical analysis:}

Statistical analyses of experimental data were carried out according to ANOVA procedures (Snedecor and Cochran, 1999). Treatment means were compared at 5\% level of probability by Duncan's New Multiple Range Test using Computer Statistical Package (CO-STAT) User Manual Version 3.03, Barkley Co.

\section{RESULTS}

\section{Effect on nematode developmental parameters:}

Effect of the tested treatments on $M$. incognita reproductive parameters 2,4 and 6 months after treatments in two separate field experiments are listed in Tables ( 1 and 2). In Experiment $I$, Nemakill reduced the $J_{2}$ number in soil after two months by $59 \%$, followed by Nema Plus Zero (57\%), H. bacteriophora (IJs) in water suspensions treatment (46\%), Micronema (42\%), Oxamyl (40\%), Nemaless (26\%) and $H$. bacteriophora as insect treatment (22\%), respectively. After four months, the highest percentage reduction was recorded with Nemaless (99\%), followed by $H$. bacteriophora (IJs) in water suspensions (83\%) and Micronema (80\%). After six months of treatment, the greatest reduction of $\mathrm{J}_{2}$ in soil, was obtained with Nemakill (88\%), followed by Micronema (87\%), Nemaless (85\%) and Oxamyl (80\%), respectively. All treatments significantly reduced numbers of each $\mathbf{J}_{2}$ in roots, galls and egg masses, compared to untreated control 2, 4 and 6 months after treatment applications (Table 1).

In experiment II, Nemakill reduced the $\mathrm{J}_{2}$ number in soil after two months by $46 \%$, followed by Oxamyl (29\%), Micronema (25\%), each of Nemaless or Nema Plus Zero (17\%), and each of liquid IJs treatment or Galleria mellonella infected with $H$. bacteriophora (6\%), respectively. After four months, the highest percentage reduction was recorded with Oxamyl (46\%), followed by Micronema (44\%) and Nemakill (40\%). After six months of treatment, the greatest reduction of $\mathrm{J}_{2}$ in soil, was obtained with Nemakill (82\%), followed by Oxamyl (73\%), Nema Plus Zero (72\%), and Micronema (66\%), respectively. All treatments significantly reduced numbers of each $\mathrm{J}_{2}$ in roots, galls and egg masses, compared to untreated plots 2, 4 and 6 months after applications (Table 2).

\section{Effect on strawberry growth and yield parameters:}

Effect of the applied treatments on growth parameters of strawberry viz. shoot length, fresh \& dry shoot weights and root fresh weight as well as yield parameters as one harvest per plant, one harvest per plot and yield per plot-season of the two field experiments are shown in Tables (3 and 4). In experiment I, the shoot length ranged from 21.0 to $24.7 \mathrm{~cm}$ in treated plots, compared to $19 \mathrm{~cm}$ in the untreated control. The fresh and dry weights of shoots and fresh root weights were in the ranges of 36.9-75.6 g, 13.70-18.33 g and 10.0-14.6 g, compared to 40.3, 9.88 and $9.1 \mathrm{~g}$ in the untreated check, respectively. The yield weight of one harvest per plant, the fruit yield of one harvest per plot, and the fruit yield per plot-season of treated plants 
Table 1. Effect of bio-control agents and chemical nematicides on developmental parameters of Meloidogyne incognita infecting strawberry cv. Festival under field conditions (Experiment I).

\begin{tabular}{|c|c|c|c|c|c|c|c|c|c|c|c|c|c|}
\hline \multirow{3}{*}{ Treatments } & \multicolumn{13}{|c|}{ Nematode parameters at months after transplanting } \\
\hline & \multirow{2}{*}{$\begin{array}{c}\text { Initial } \\
\mathrm{J}_{2} \\
\text { in soil }\end{array}$} & \multicolumn{2}{|c|}{ Two } & \multicolumn{5}{|c|}{ Four } & \multicolumn{5}{|c|}{ Six } \\
\hline & & $\mathrm{J}_{2}$ in soil & $\begin{array}{c}\text { Red. } \\
\%\end{array}$ & $\begin{array}{l}\mathrm{J}_{2} \text { in } \\
\text { soil }\end{array}$ & $\begin{array}{c}\text { Red. } \\
\%\end{array}$ & $\begin{array}{c}\mathrm{J}_{2} \\
\text { in roots }\end{array}$ & $\begin{array}{c}\text { Galls } \\
\text { No. }\end{array}$ & $\begin{array}{c}\text { Egg } \\
\text { masses }\end{array}$ & $\begin{array}{l}\mathrm{J}_{2} \text { in } \\
\text { soil }\end{array}$ & $\begin{array}{c}\text { Red. } \\
\%\end{array}$ & $\begin{array}{l}\mathrm{J}_{2} \text { in } \\
\text { roots }\end{array}$ & $\begin{array}{l}\text { Galls } \\
\text { No. }\end{array}$ & $\begin{array}{c}\text { Egg } \\
\text { masses }\end{array}$ \\
\hline Nemakill $^{@}$ & $110 b^{*}$ & $35 \mathrm{~d}$ & 59 & $160 \mathrm{c}$ & 58 & $125 b$ & $2 \mathrm{bc}$ & $1 \mathrm{~b}$ & $120 \mathrm{e}$ & 88 & $60 \mathrm{~g}$ & $6 \mathrm{~d}$ & $3 \mathrm{~d}$ \\
\hline Nemaless $^{@}$ & 70ef & $40 c$ & 26 & $150 \mathrm{~d}$ & 99 & $50 \mathrm{~d}$ & $1 \mathrm{c}$ & $1 \mathrm{~b}$ & $100 \mathrm{f}$ & 85 & $70 f$ & $4 \mathrm{e}$ & $2 \mathrm{~d}$ \\
\hline Micronema $^{@}$ & $100 \mathrm{c}$ & $45 b$ & 42 & $70 \mathrm{~g}$ & 80 & $50 \mathrm{~d}$ & $2 \mathrm{bc}$ & $2 \mathrm{~b}$ & $120 \mathrm{e}$ & 87 & $70 f$ & $3 e$ & $2 \mathrm{~d}$ \\
\hline $\begin{array}{l}\text { Heterorhabditis } \\
\text { bacteriophora in water }\end{array}$ & $120 \mathrm{a}$ & $50 a$ & 46 & $70 \mathrm{~g}$ & 83 & $40 \mathrm{e}$ & $1 \mathrm{c}$ & $1 b$ & $400 \mathrm{~b}$ & 64 & $130 \mathrm{e}$ & $8 \mathrm{c}$ & $6 b c$ \\
\hline $\begin{array}{l}\text { Heterorhabditis } \\
\text { bacteriophora in insect }\end{array}$ & $75 \mathrm{e}$ & $45 b$ & 22 & $133 \mathrm{e}$ & 49 & $50 \mathrm{~d}$ & $2 \mathrm{bc}$ & $2 b$ & $320 \mathrm{c}$ & 54 & $200 b$ & $10 \mathrm{~b}$ & $7 b$ \\
\hline Nema Plus Zero ${ }^{@}$ & 90d & $30 \mathrm{e}$ & 57 & $180 \mathrm{~b}$ & 42 & $60 c$ & $3 b$ & $2 b$ & $300 d$ & 64 & $150 d$ & $7 \mathrm{~cd}$ & $5 c$ \\
\hline Oxamyl & $65 f g$ & $30 \mathrm{e}$ & 40 & $100 f$ & 55 & $50 \mathrm{~d}$ & $2 \mathrm{bc}$ & $2 b$ & $120 \mathrm{e}$ & 80 & $180 \mathrm{c}$ & $4 \mathrm{e}$ & $3 d$ \\
\hline Untreated & $60 \mathrm{~g}$ & $45 b$ & - & 210 & - & $130 \mathrm{a}$ & $10 \mathrm{a}$ & $7 \mathrm{a}$ & $560 \mathrm{a}$ & - & $900 \mathrm{a}$ & $23 a$ & $14 a$ \\
\hline
\end{tabular}

*Means, averages of five plots followed by same letter(s) in a column are not significant (P $\leq 0.05)$ according to Duncan's Multiple Range Test 
Table 2. Effect of bio-control agents and chemical nematicides on developmental parameters of Meloidogyne incognita infecting strawberry cv. Fertona under field conditions (Experiment II).

\begin{tabular}{|c|c|c|c|c|c|c|c|c|c|c|c|c|c|}
\hline \multirow{3}{*}{ Treatments } & \multicolumn{13}{|c|}{ Nematode parameters at months after transplanting } \\
\hline & \multirow{2}{*}{$\begin{array}{c}\text { Initial } \\
\mathrm{J}_{2} \text { in soil }\end{array}$} & \multicolumn{2}{|c|}{ Two } & \multicolumn{5}{|c|}{ Four } & \multicolumn{5}{|c|}{ Six } \\
\hline & & $\begin{array}{l}\mathrm{J}_{2} \text { in } \\
\text { soil }\end{array}$ & $\begin{array}{c}\text { Red. } \\
\%\end{array}$ & $\begin{array}{l}\mathrm{J}_{2} \text { in } \\
\text { soil }\end{array}$ & $\begin{array}{c}\text { Red. } \\
\%\end{array}$ & $\begin{array}{l}\mathrm{J}_{2} \text { in } \\
\text { roots }\end{array}$ & $\begin{array}{l}\text { Galls } \\
\text { No. }\end{array}$ & $\begin{array}{c}\text { Egg } \\
\text { masses }\end{array}$ & $\begin{array}{l}\mathrm{J}_{2} \text { in } \\
\text { soil }\end{array}$ & $\begin{array}{c}\text { Red. } \\
\%\end{array}$ & $\begin{array}{l}\mathrm{J}_{2} \text { in } \\
\text { roots }\end{array}$ & $\begin{array}{l}\text { Galls } \\
\text { No. }\end{array}$ & $\begin{array}{c}\text { Egg } \\
\text { masses }\end{array}$ \\
\hline Nemakill $^{@}$ & $70 b^{2}$ & $30 c^{*}$ & 46 & $100 \mathrm{c}$ & 40 & $40 \mathrm{~b}$ & $1 \mathrm{~b}$ & $1 \mathrm{~b}$ & 60f & 82 & $180 \mathrm{~d}$ & $3 d$ & $2 \mathrm{c}$ \\
\hline Nemaless ${ }^{@}$ & $30 \mathrm{f}$ & $20 \mathrm{~d}$ & 17 & $60 \mathrm{f}$ & 16 & $20 \mathrm{~d}$ & $1 \mathrm{~b}$ & $1 \mathrm{~b}$ & $100 \mathrm{c}$ & 30 & $210 \mathrm{c}$ & $4 \mathrm{~cd}$ & $2 \mathrm{c}$ \\
\hline Micronema ${ }^{@}$ & $50 \mathrm{~d}$ & $30 \mathrm{c}$ & 25 & $60 f$ & 44 & $20 \mathrm{~d}$ & $2 b$ & $1 \mathrm{~b}$ & $80 \mathrm{e}$ & 66 & $130 \mathrm{~g}$ & $3 d$ & $3 c$ \\
\hline $\begin{array}{l}\text { Heterorhabditis bacteriophora in } \\
\text { water }\end{array}$ & $40 \mathrm{e}$ & $30 \mathrm{c}$ & 6 & $133 b$ & -37 & $20 d$ & $2 b$ & $1 \mathrm{~b}$ & $90 \mathrm{~d}$ & 53 & $180 \mathrm{~g}$ & $5 c$ & $4 \mathrm{bc}$ \\
\hline $\begin{array}{l}\text { Heterorhabditis bacteriophora in } \\
\text { insect }\end{array}$ & $40 \mathrm{e}$ & $30 c$ & 6 & $100 \mathrm{c}$ & -56 & $30 \mathrm{c}$ & $2 b$ & $1 \mathrm{~b}$ & $120 \mathrm{~b}$ & 37 & $220 b$ & $7 b$ & $5 b$ \\
\hline Nema Plus Zero ${ }^{@}$ & $60 c$ & $40 b$ & 17 & $90 \mathrm{~d}$ & 37 & $30 \mathrm{c}$ & $1 b$ & $0 \mathrm{c}$ & $80 \mathrm{e}$ & 72 & $140 \mathrm{f}$ & $4 \mathrm{~cd}$ & $2 c$ \\
\hline Oxamyl & $70 \mathrm{~b}$ & $40 b$ & 29 & $80 \mathrm{e}$ & 46 & $20 \mathrm{~d}$ & $1 b$ & $0 \mathrm{c}$ & $90 \mathrm{~d}$ & 73 & $150 \mathrm{e}$ & $4 \mathrm{~cd}$ & $3 c$ \\
\hline Untreated & $75 a$ & $60 a$ & - & $160 \mathrm{a}$ & - & $80 a$ & $7 a$ & $5 a$ & $350 a$ & - & $700 \mathrm{a}$ & $18 \mathrm{a}$ & $13 a$ \\
\hline
\end{tabular}

*Means, averages of five plots, followed by same letter(s) in a column are not significant (P $\leq 0.05)$ according to Duncan's Multiple Range Test. 
Table 3. Effect of bio-control agents and chemical nematicides on growth and yield of strawberry cv. Festival infected by Meloidogyne incognita under field conditions (Experiment I).

\begin{tabular}{|c|c|c|c|c|c|c|c|}
\hline \multirow{3}{*}{ Treatments } & \multicolumn{7}{|c|}{ Growth and Yield parameters } \\
\hline & \multicolumn{4}{|c|}{ Growth } & \multicolumn{3}{|c|}{ Yield } \\
\hline & $\begin{array}{l}\text { Shoot Length } \\
(\mathrm{cm})\end{array}$ & $\begin{array}{l}\text { Shoot fresh } \\
\text { weight }(g)\end{array}$ & $\begin{array}{l}\text { Shoot dry } \\
\text { weight }(\mathrm{g})\end{array}$ & $\begin{array}{l}\text { Root fresh } \\
\text { weight }(\mathrm{g})\end{array}$ & $\begin{array}{l}\text { Plant/ one } \\
\text { harvest (g) }\end{array}$ & $\begin{array}{c}\text { Plot /one } \\
\text { harvest }(\mathrm{kg})\end{array}$ & $\begin{array}{l}\text { Plot /season } \\
\quad(\mathrm{kg})\end{array}$ \\
\hline Nemakill $^{@}$ & $24.7 a^{*}$ & $75.6 \mathrm{a}$ & $18,33 \mathrm{a}$ & $11.9 \mathrm{ab}$ & $68.7 \mathrm{a}$ & $3.02 \mathrm{a}$ & $48.37 \mathrm{a}$ \\
\hline Nemaless $^{@}$ & $23.7 \mathrm{ab}$ & $36.9 \mathrm{c}$ & $17.24 \mathrm{~b}$ & $10.0 \mathrm{ab}$ & $48.5 \mathrm{~d}$ & $2.13 \mathrm{~d}$ & $34.15 d$ \\
\hline Micronema $^{\Theta}$ & $23.3 \mathrm{ab}$ & $67.1 \mathrm{abc}$ & $16.66 \mathrm{~b}$ & $13.0 \mathrm{ab}$ & $47.0 \mathrm{~d}$ & $2.07 \mathrm{~d}$ & $33.09 \mathrm{~d}$ \\
\hline $\begin{array}{l}\text { Heterorhabditis bacteriophora } \\
\text { in water }\end{array}$ & $24.7 \mathrm{a}$ & $74.8 \mathrm{ab}$ & $18.19 \mathrm{a}$ & $12.9 \mathrm{ab}$ & $61.3 b$ & $2.70 \mathrm{~b}$ & $43.16 \mathrm{~b}$ \\
\hline $\begin{array}{l}\text { Heterorhabditis bacteriophora } \\
\text { in insect }\end{array}$ & $21.7 \mathrm{ab}$ & $51.6 a b c$ & $13.70 \mathrm{~d}$ & $14.3 \mathrm{a}$ & $53.1 \mathrm{c}$ & $2.34 \mathrm{c}$ & $37.38 \mathrm{c}$ \\
\hline Nema Plus Zero $^{@}$ & $22.0 \mathrm{ab}$ & $53.1 \mathrm{abc}$ & $15.50 \mathrm{c}$ & $14.6 \mathrm{a}$ & $37.7 \mathrm{e}$ & $1.66 \mathrm{e}$ & $26.52 \mathrm{e}$ \\
\hline Oxamyl & $21.0 \mathrm{ab}$ & $51.7 \mathrm{abc}$ & $15.38 \mathrm{c}$ & $11.0 \mathrm{ab}$ & $32.0 \mathrm{f}$ & $1.41 \mathrm{f}$ & $22.53 \mathrm{f}$ \\
\hline Untreated & $19.0 \mathrm{~b}$ & $40.3 b c$ & $9.88 \mathrm{~d}$ & $9.1 \mathrm{~b}$ & $26.8 \mathrm{~g}$ & $1.18 \mathrm{~g}$ & $18.87 \mathrm{~g}$ \\
\hline
\end{tabular}

*Means, averages of five plots, followed by same letter(s) in a column are not significant $(\mathrm{P} \leq 0.05)$ according to Duncan's Multiple Range Test. 
Table 4. Effect of bio-control agents and chemical nematicides on growth and yield of strawberry cv. Fertona infected by Meloidogyne incognita under field conditions (Experiment II).

\begin{tabular}{|c|c|c|c|c|c|c|c|}
\hline \multirow{3}{*}{ Treatments } & \multicolumn{7}{|c|}{ Growth and Yield parameters } \\
\hline & \multicolumn{4}{|c|}{ Growth } & \multicolumn{3}{|c|}{ Yield } \\
\hline & Shoot Length $(\mathrm{cm})$ & $\begin{array}{l}\text { Shoot fresh } \\
\text { weight (g) }\end{array}$ & $\begin{array}{l}\text { Shoot dry } \\
\text { weight (g) }\end{array}$ & $\begin{array}{l}\text { Root fresh } \\
\text { weight }(\mathrm{g})\end{array}$ & $\begin{array}{l}\text { Plant/one } \\
\text { harvest }(\mathrm{g})\end{array}$ & $\begin{array}{c}\text { Plot /one } \\
\text { harvest (kg) }\end{array}$ & $\begin{array}{c}\text { Plot /season } \\
(\mathrm{kg})\end{array}$ \\
\hline Nemakill $^{@}$ & $20.0 \mathrm{abc}^{*}$ & $58.3 \mathrm{abc}$ & $15.20 \mathrm{f}$ & $14.8 \mathrm{ab}$ & $86.6 b$ & $3.81 b$ & $60.97 b$ \\
\hline Nemaless $^{@}$ & $23.0 \mathrm{a}$ & 66.9ab & $17.27 \mathrm{e}$ & $16.0 \mathrm{ab}$ & $94.8 \mathrm{a}$ & $4.17 \mathrm{a}$ & $66.76 a$ \\
\hline Micronema $^{@}$ & 20.0abc & $64.2 \mathrm{ab}$ & $18.94 \mathrm{c}$ & $14.6 a b$ & $83.6 b$ & $3.68 b$ & $58.85 b$ \\
\hline $\begin{array}{l}\text { Heterorhabditis bacteriophora } \\
\text { in water }\end{array}$ & $20.7 \mathrm{abc}$ & 61.6abc & $18.40 \mathrm{~d}$ & $19.5 \mathrm{a}$ & $62.0 \mathrm{c}$ & $2.73 c$ & $43.65 \mathrm{c}$ \\
\hline $\begin{array}{l}\text { Heterorhabditis bacteriophora } \\
\text { in insect }\end{array}$ & $20.7 \mathrm{abc}$ & $83.8 \mathrm{ab}$ & $25.04 \mathrm{a}$ & $17.5 \mathrm{ab}$ & $63.2 \mathrm{c}$ & $2.78 \mathrm{c}$ & $44.49 \mathrm{c}$ \\
\hline Nema Plus Zero ${ }^{@}$ & $22.3 \mathrm{ab}$ & $88.0 \mathrm{a}$ & $24.30 \mathrm{~b}$ & $15.6 \mathrm{ab}$ & $57.2 \mathrm{c}$ & $2.52 \mathrm{c}$ & $40.27 \mathrm{c}$ \\
\hline Oxamyl & $18.0 \mathrm{bc}$ & $55.1 \mathrm{bc}$ & $14.46 \mathrm{~g}$ & $16.3 \mathrm{ab}$ & $57.3 \mathrm{c}$ & $2.52 \mathrm{c}$ & $40.34 c$ \\
\hline Untreated & $16.7 \mathrm{c}$ & $31.4 \mathrm{c}$ & $10.98 \mathrm{~h}$ & $11.1 \mathrm{~b}$ & $32.2 \mathrm{~d}$ & $1.42 \mathrm{~d}$ & $22.67 d$ \\
\hline
\end{tabular}

*Means, averages of five plots, followed by same letter(s) in a column are not significant ( $\mathrm{P} \leq 0.05)$ according to Duncan's Multiple Range Test. 
ranged $32.0-68.7 \mathrm{~g}, 1.41-3.02 \mathrm{~kg}$, and $22.53-48.37 \mathrm{~kg}$, compared to $26.8 \mathrm{~g}, 1.18 \mathrm{~kg}$, and $18.87 \mathrm{~kg}$ in the untreated plots, respectively (Table 3). Nemakill followed by EPNs in water and within insect gave best fruit yield of strawberry cv. Festival. In experiment II, the shoot length in treated plots ranged $18.0-23.0 \mathrm{~cm}$ compared to length of $16.7 \mathrm{~cm}$ in the untreated control. The fresh and dry weight of shoot and fresh weight of roots were in the ranges of 55.1- 88.0 g, 14.46-25.04 $\mathrm{g}$ and 14.6-17.5 $\mathrm{g}$, compared to $40.30,9.88$ and $9.10 \mathrm{~g}$ in the untreated plants, respectively. Yield weight of one harvest per plant, fruit yield of one harvest per plot, and fruit yield per plot-season ranged 57.2-94.8 g, 2.52-4.17 kg, and 40.27-66.76 kg, compared to 32.2 $\mathrm{g}, 1.42 \mathrm{~kg}$ and $22.67 \mathrm{~kg}$ in untreated control, respectively (Table 4). Nemaless followed by Nemakill and Micronema gave best fruit yield of strawberry cv. Fertona.

\section{Effect on rhizosphere microbial counts:}

Effect of the applied treatments on total microbial counts of aerobic bacteria, spore-forming bacteria and total fungi in the two field experiments are listed in Table (5). In experiment I, the total aerobic bacteria counts in the rhizosphere of strawberry ranged from 7.06 to $7.57 \log _{10} \mathrm{CFU} / 10 \mathrm{~g}$ soil, the spore-forming bacteria counts ranged 4.98-5.26 $\log _{10} \mathrm{CFU} / 10 \mathrm{~g}$ soil, while the total fungi counts ranged from 4.27 to $4.53 \log _{10}$ CFU/10g soil, compared to counts of $7.55,5.28$ and $4.47 \log _{10} \mathrm{CFU} / 10 \mathrm{~g}$ soil, in untreated plots, respectively.

In experiment II, the total aerobic bacteria counts in the rhizosphere of strawberry ranged from 7.11 to $7.57 \log _{10} \mathrm{CFU} / 10 \mathrm{~g}$ soil, the spore-forming bacteria counts ranged from $4.97-5.27 \log _{10} \mathrm{CFU} / 10 \mathrm{~g}$ soil, while the total fungi counts ranged from 4.28 to $4.52 \log _{10} \mathrm{CFU} / 10 \mathrm{~g}$ soil, compared to counts of $7.58,5.29$ and 4.44 $\log _{10}$ CFU/10g soil in the untreated plants, respectively (Table 5). Yet, Aspergillus spp. and Penicillium spp had higher frequency than others. Details of frequency of the common fungi in two field experiments are listed in Tables (6 and 7).

\section{DISCUSSION}

Environmental and health concerns over the use of chemical pesticides have increased the need for alternative measures to control plant-parasitic nematodes. Biological control is considered ecologically friendly and a potential alternative in pest and disease management. Therefore, we examined the effect of a few biocontrol agents, in the form of commercial and EPN products compared herein to the chemical nematicides Nema Plus Zero and Oxamyl, on $M$. incognita population densities, rhizosphere microbial community, and strawberry growth and yield in two field experiments. Nemakill, Nemaless and Micronema could highly reduce $M$. incognita$\mathbf{J}_{2}$ in soil than EPNs especially after four and six months of transplanting strawberry cv. Festival, while Nemakill, Nemaless and Micronema were the best for strawberry cv. Fertona. Yet, all tested treatments enhanced strawberry growth parameters viz. shoot length, fresh \& dry shoot weights and fresh root weights as well as yield parameters of both cultivars. These results partially agreed with those recorded by ElNagdi and Abd-El-Khair (2014) where Micronema and other biocontrol agents significantly reduced $M$. incognita population levels and increased common bean yield. Also, the highest percentages reduction of juveniles $\left(\mathrm{J}_{2}\right)$ in soil and each of $\mathbf{J}_{2}$, $\mathrm{J}_{3}$, females and eggs in roots were achieved by Fornem $\times 5^{\circledR}$, followed by Micronema ${ }^{\circledR}$ after six months of application (El-Nagdi et al., 2015). Combining apple fruit fermentation plus Bacillus licheniformis in one treatment resulted the largest leaf area, 
plant height, root length and plant weight (Zhang et al., 2016). Such a combination could increase antioxidant enzymes activities in strawberry seedlings, optimize the status of rhizosphere microbial, and promote plant growth.

Table 5. Effect of bio-control agents and chemical nematicides on total microbial counts in the rhizosphere of strawberry cvs Festival (Exp. I ) and Fertona (Exp. II ) six months after transplanting under field conditions.

\begin{tabular}{|c|c|c|c|c|c|c|}
\hline \multirow{3}{*}{ Treatments } & \multicolumn{6}{|c|}{ Total microbial counts $\left(\log _{10} \mathrm{CFU} / 10 \mathrm{~g}\right.$ soil) } \\
\hline & \multicolumn{2}{|c|}{$\begin{array}{l}\text { Aerobic bacteria } \\
\qquad\left(10^{6}\right)\end{array}$} & \multicolumn{2}{|c|}{$\begin{array}{l}\text { Spore-forming } \\
\text { bacteria }\left(10^{4}\right)\end{array}$} & \multicolumn{2}{|c|}{$\begin{array}{l}\text { Total fungi } \\
\qquad\left(10^{3}\right)\end{array}$} \\
\hline & Exp. I & Exp. II & Exp. I & Exp. II & Exp. I & Exp. II \\
\hline Nemakill $^{@}$ & $7.46 b^{*}$ & $7.23 \mathrm{~d}$ & $5.17 \mathrm{bc}$ & $4.97 \mathrm{~d}$ & $4.27 \mathrm{~b}$ & $4.33 \mathrm{ab}$ \\
\hline Nemaless ${ }^{@}$ & $7.57 \mathrm{a}$ & $7.57 \mathrm{a}$ & $5.26 a b$ & $5.27 \mathrm{a}$ & $4.32 b$ & $4.38 \mathrm{ab}$ \\
\hline Micronema ${ }^{@}$ & $7.31 \mathrm{c}$ & $7.40 \mathrm{~b}$ & $5.03 \mathrm{de}$ & $5.10 \mathrm{~b}$ & $4.28 \mathrm{~b}$ & $4.28 \mathrm{~b}$ \\
\hline $\begin{array}{l}\text { H.bacteriophora in } \\
\text { water }\end{array}$ & $7.55 \mathrm{a}$ & $7.56 \mathrm{a}$ & $5.15 \mathrm{c}$ & $5.00 \mathrm{~cd}$ & $4.51 \mathrm{a}$ & $4.28 b$ \\
\hline $\begin{array}{l}\text { H.bacteriophora in } \\
\text { insect }\end{array}$ & $7.06 \mathrm{~d}$ & $7.11 \mathrm{e}$ & $5.03 \mathrm{de}$ & $5.01 \mathrm{~cd}$ & $4.46 \mathrm{a}$ & $4.45 \mathrm{ab}$ \\
\hline Nema Plus Zero@ $^{@}$ & $7.27 \mathrm{c}$ & $7.30 \mathrm{c}$ & $4.98 \mathrm{e}$ & $5.02 \mathrm{c}$ & $4.53 \mathrm{a}$ & $4.46 \mathrm{ab}$ \\
\hline Oxamyl & $7.25 \mathrm{c}$ & $7.27 \mathrm{~cd}$ & $5.10 \mathrm{~cd}$ & $5.00 \mathrm{~cd}$ & $4.51 \mathrm{a}$ & $4.52 \mathrm{a}$ \\
\hline Untreated & $7.55 \mathrm{a}$ & $7.58 \mathrm{a}$ & $5.28 \mathrm{a}$ & $5.29 a$ & $4.47 \mathrm{a}$ & $4.44 a b$ \\
\hline
\end{tabular}

*Means are averages of five plots followed by same small letter (s) in a column are not significant according to Duncan's Multiple Range Test at $\mathrm{P} \leq 0.05$.

Our results showed that some tested treatments affected the rhizosphere microbial levels as well as the frequency of common fungi, compared to the untreated control. These results are in agreement with those recorded by Abd-El-Khair and El-Nagdi (2014) found also that other biocontrol agents; i.e. Trichoderma album, T. viride, Rhizo-N® (Bacillus subtilis), Bio-Arc ${ }^{\circ},(B a c i l l u s ~ m e g a t e r i u m)$ and Bio-Zeid ${ }^{\circ},(T$. album), induced significant differences in counts of bacteria and fungi in the rhizosphere of potato plants under field conditions. They also reported that Aspergillus spp., A. niger, Fusarium solani, Penicillium spp., Rhizopus spp., Rhizoctonia solani, and Trichoderma spp. were the common fungi in the rhizosphere of treated potato. ElNagdi and Abd-El-Khair (2014) showed that Aspergillus spp., A. niger, Fusarium spp., F. solani, Penicillium spp., $R$. solani, $R$. nigricans and Trichoderma spp.were the common fungi in the rhizospheres of common bean plants treated with Stanes sting ${ }^{\circledR}$ (Bacillus subtilis), Bio-Nematon ${ }^{\circledR}$ (Paecilomyces lilacinus), T. hamatum, T. album, Stanes symbion vam plus ${ }^{\circledR}$ (Glomus fasciculatum and Gigaspora sp.) and Rhizo-N ${ }^{\circledR}$ 
Table 6. Effect of bio-control agents and chemical nematicides on the frequency (\%) of fungi in the rhizosphere of strawberry cv.Festival six months after transplanting under field conditions (Experiment I).

\begin{tabular}{|c|c|c|c|c|c|c|c|c|}
\hline \multirow[b]{2}{*}{ Fungi } & \multicolumn{8}{|c|}{ Frequency $\%$ of fungi in treatments } \\
\hline & Nemakill $^{@}$ & Nemaless $^{@}$ & Micronema $^{@}$ & $\begin{array}{c}\text { H. bacteriophora } \\
\text { in water }\end{array}$ & $\begin{array}{l}\text { H. bacteriophora in } \\
\text { insect }\end{array}$ & $\begin{array}{c}\text { Nema Plus } \\
\text { Zero }^{@}\end{array}$ & Oxamyl & Untreated \\
\hline Aspergillus spp. & 7.7 & 9.7 & 18.6 & 16.7 & 15.6 & 15.9 & 11.8 & 8.9 \\
\hline Aspergillus niger & 7.7 & 6.5 & 2.3 & 13.9 & 11.8 & 9.1 & 8.8 & 5.9 \\
\hline A.terreus & 3.9 & 0 & 9.3 & 2.8 & 0 & 6.8 & - & 2.9 \\
\hline Alternaria spp. & 3.9 & 3.2 & 2.3 & 0 & 3.1 & 2.3 & - & 5.9 \\
\hline Botrytis spp. & 3.9 & 0 & 0 & 0 & 0 & 2.3 & 2.9 & 5.9 \\
\hline Penicillium spp. & 23.1 & 25.9 & 27.9 & 16.7 & 15.6 & 20.5 & 20.6 & 14.7 \\
\hline P. chrysogenum & 15.4 & 16.1 & 16.3 & 8.3 & 9.4 & 11.4 & 20.6 & 8.9 \\
\hline P. citrinum & 11.5 & 16.1 & 9.3 & 5.6 & 11.8 & 13.6 & 17.7 & 8.9 \\
\hline Rhizopus nigricans & 7.7 & 9.7 & 0 & 13.9 & 11.8 & 2.3 & 5.9 & 11.8 \\
\hline Rhizoctonia solani & 3.9 & 3.2 & 4.7 & 5.6 & 3.1 & 2.3 & 2.9 & 8.9 \\
\hline Fusarium spp. & 3.9 & 3.2 & 4.7 & 8.3 & 6.3 & 6.8 & 2.9 & 11.8 \\
\hline Trichoderma spp. & 3.9 & 3.2 & 2.3 & 5.6 & 3.1 & 4.6 & - & - \\
\hline Others & 3.5 & 3.2 & 2.3 & 2.6 & 8.4 & 2.1 & 5.2 & 5.5 \\
\hline
\end{tabular}


Table 7. Effect of bio-control agents and chemical nematicides on the frequency (\%) of fungi in the rhizosphere of strawberry cv. Fertona six months after transplanting under field application (Experiment II).

\begin{tabular}{|c|c|c|c|c|c|c|c|c|}
\hline \multirow[b]{2}{*}{ Fungi } & \multicolumn{8}{|c|}{ Frequency $\%$ of fungi in treatments } \\
\hline & Nemakill $^{@}$ & Nemaless $^{@}$ & Micronema $^{\varrho}$ & $\begin{array}{l}\text { H. bacteriophora in } \\
\text { water }\end{array}$ & $\begin{array}{c}\text { H. bacteriophora in } \\
\text { insect }\end{array}$ & $\begin{array}{c}\text { Nema Plus } \\
\text { Zero }^{@}\end{array}$ & Oxamyl & Untreated \\
\hline Aspergillus spp. & 20.6 & 19.2 & 14.3 & 17.1 & 18.2 & 16.2 & 17.7 & 12.8 \\
\hline Aspergillus niger & 8.8 & 7.7 & 2.9 & 5.7 & 9.1 & 8.1 & 5.9 & 5.1 \\
\hline A. terreus & 11.8 & 7.7 & - & 5.7 & 3.0 & 5.4 & 5.9 & 5.1 \\
\hline Alternaria spp. & 2.9 & 3.9 & 5.7 & 2.9 & 6.1 & 2.7 & 5.9 & 7.7 \\
\hline Botrytis spp. & 2.9 & 3.9 & - & 2.9 & 3.0 & 2.7 & 2.9 & 5.1 \\
\hline Penicillium spp. & 11.8 & 15.4 & 25.7 & 22.9 & 21.2 & 10.2 & 20.6 & 12.8 \\
\hline P. chrysogenum & 2.9 & 11.5 & 20.0 & 14.3 & 15.2 & 16.2 & 11.7 & 7.7 \\
\hline P. citrinum & 5.9 & 7.7 & 14.3 & 11.4 & 12.1 & 13.5 & 8.8 & 7.7 \\
\hline Rhizopus nigricans & 11.8 & 7.7 & 2.9 & 5.7 & 3.0 & 5.4 & 5.9 & 5.1 \\
\hline Rhizoctonia solani & 5.9 & 3.9 & 2.9 & 2.9 & 3.0 & 5.4 & 2.9 & 12.8 \\
\hline Fusarium spp. & 2.9 & 3.9 & 5.7 & 5.7 & 3.0 & 8.1 & 5.9 & 10.3 \\
\hline Trichoderma spp. & 8.8 & 3.9 & - & - & - & 2.7 & 2.9 & 2.6 \\
\hline Others & 3.0 & 3.6 & 5.7 & 2.8 & 3.1 & 2.8 & 3.0 & 5.2 \\
\hline
\end{tabular}


(B. subtilis) in field application. Li et al. (2012) reported that such specific bacterial and fungal genera were common communities in different replant soils of strawberry,where the numbers of both bacterial and fungal communities increased in the replant strawberry soil. Zhang et al. (2016) showed that the greatest numbers of bacterial species were observed in the rhizosphere of control matrix treated with water only, while the lowest diversity appeared in the rhizosphere soil treated with $B$. licheniformis alone. Jang et al. (2016) found that a culture filtrate of A. niger F22 was highly active against $M$. incognita with marked mortality of second-stage juveniles and inhibition of egg hatching, where the nematicidal component was identified as oxalic acid. Application of $A$. niger in a field naturally infested with $M$. incognita, significantly reduced gall formation on the roots of watermelon plants (Jang et al., 2016). These results suggest that A. niger can be used as a microbial nematicide for the control of root-knot nematode disease. The data presented herein documented the importance of the rhizosphere for plant nutrition, health and quality, where the response of microorganisms to root exudates was shown to shape rhizosphere microbial communities (Berg and Smalla, 2009). This complex plant-associated microbial community is crucial for crop production. Berendsen et al. (2012) reported that different plant species may host specific microbial communities when grown on the same soil. So, plants affect their rhizosphere microbial communities that can contain beneficial effect, where one of the mechanisms of disease control is induced systemic resistance (ISR). Such ISR is effective against a wide range of pathogens and thus offers important potential for practical applications in crop protection (Doornbos et al., 2012).

\section{ACKNOWLEDGEMENT}

This study was supported in part by the US-Egypt Project cycle 17 (no. 172) entitled 'Preparing and evaluating IPM tactics for increasing strawberry and citrus production'.

\section{REFERENCES}

Abd-El-Khair, H. and El-Nagdi, Wafaa M.A. (2014). Field application of bio-control agents for controlling fungal root rot and root-knot nematode in potato. Arch. Phytopathol. Plant Prot. 47(10):1218-1230.

Barker, K.R. (1985). Nematode Extraction and Bioassays. Pp. 19-35. In: An Advanced Treatise on Meloidogyne - Vol. II (Barker K.R., Carter C.C. and Sasser J.N., eds). North Carolina State University Graphics, Raleigh, USA.

Barnett, H.L. and Hunter, B.B. (1972). Illustrated Genera of Imperfect Fungi. Burgess Publ. Co., Minnesota, 241 pp.

Bélair, G. and Khanizadeh, S. (1994). Distribution of plant-parasitic nematodes in strawberry and raspberry fields in Quebec. Phytoprotection 75(2): 101-107.

Berendsen, R. L., Pieterse, C.M.J. and Bakker, P.A.H.M. (2012). The rhizosphere microbiome and plant health. Trends Plant Sci. 17(8): 478 - 486.

Berg, G. and Smalla, K. (2009). Plant species and soil type cooperatively shape the structure and function of microbial communities in the rhizosphere. FEMS Microbiol. Ecol. 68 (1): 1-13.

Bianco, L., Lopez, L., Scalone, A. G., Carli, M. D., Desiderio, A., Benvenuto, E. and Perrotta, G. (2009). Strawberry proteome characterization and its regulation during fruit ripening and in different genotypes. J. Proteomics 72(4): 586-607. 
Bombarely, A.; Merchante, C.; Csukasi, F.; Rus, E.C.; Caballero, J.L.; Escobar, N.M.; Portales, R.B.; Botella, M.A.; Blanco, J.M.; Sevilla, J.F.S. and Valpuesta, V. (2010). Generation and analysis of ESTs from strawberry (Fragaria ananassa) fruits and evaluation of their utility in genetic and molecular studies. BMC Genomics 11: 503 (Abs.).

Bridson, E.Y. (1995). The Oxide Manual $7^{\text {th }}$ Ed., Published by Unipath Limited, Wade Koad, Basingstoke Hampshire, RG 248 PW, England.

Dickstein, E.R. and Krusberg, L.R. (1978). Reaction of strawberry cultivars to the northern root-knot nematode, Meloidogyne hapla. P1. Dis. Reptr. 62: 60-61.

Doornbos, R. F.; Van Loon, L. C. and Bakker, P. A. H. M.(2012). Impact of root exudates and plant defense signaling on bacterial communities in the rhizosphere: A review. Agron. Sustainable Dev. 32:227-243.

Edwards, W.H.; Jones, R.K. and Schmitt, D.P. (1985). Host suitability and parasitism of selected strawberry cultivars by M. hapla and M. incognita. Plant Dis. 69(1): 40-42.

Ellis, M.B. (1971). Dematiaceous hyphomycetes. Commw. Mycol. Inst. Kew. Surrey, England.

El-Nagdi, Wafaa M.A. and Abd-El-Khair, H. (2014). Biological control of Meloidogyne incognita and Fusarium solani in dry common bean in the field. Arch. Phytopathol. Plant Prot. 47(4):388-397.

El-Nagdi, Wafaa M.A., Haggag, Karima H.E., Abd-El-Fattah, A. I. and Abd-ElKhair, H.(2011). Biological control of Meloidogyne incognita and Fusarium solaniin sugar beet Nematol. Medit. 39(1): 59-71

El-Nagdi, Wafaa M.A.; Abd El-Khair, H. and El-Ghonaimy, Ahalm M. (2015). Field application of biological control on root-knot nematode and Fusarium root rot fungus in Banana Cv. Grand Naine. Middle East J. Agric. Res. 4 (3): 545-554.

El-Shemy, A.A.; Khafagy, Y.S. and Al-Genteery, A.M.M. (2013). Cultivation and production of strawberry. Technical issue no. 9/2013, General Directorate of Agricultural Culture, Egyptian Ministry of agriculture, 135 p. (in Arabic).

Ghini, R.F.; Patrico, R.A.; Bettiol, W.; de Almeida, M.G. and Maia, A.H.N. (2007). Effect of sewage sludge on suppressiveness to soil-borne plant pathogens. Soil Biol. Biochem. 39:2797-2805.

Hammam, M. M. A.; El-Nagdi, Wafaa M.A and Abd-Elgawad M. M. M.(2016). Biological and chemical control of the citrus nematode, Tylenchulus semipenetrans (Cobb, 1913) on mandarin in Egypt. Egypt. J. Biol. Pest Cont. 26(2): 345-349.

Ibrahim, I.K.A. (1985). The status of root-knot nematodes in the Middle East, Region VII of the International Meloidogyne Project. In: Advanced Treatise on Meloidogyne, Vol I, Biology and Control. J.N.Sasser and C.C. Carter (Eds.). North Carolina State Univ. Graphics Raleigh, N.C. U.S.A.

Jang, J. Y., Choi, Y. H., Shin, T. S., Kim T. H., Shin, K.S., Park , H. W., Kim, H., Kim, Y. H., Choi, G. J., Jang, K. S., Cha , B., Kim, I. S., Myung, E. J. and Kim, J.C. (2016). Biological control of Meloidogyne incognita by Aspergillus niger F22 producing Oxalic Acid. PLoS One, 11(6): e0156230. Doi: 10.1371/ journal. pone. 0156230

Kurze, S.; Bahl, H.; Dahl, R. and Berg, G.(2001). Biological control of fungal strawberry diseases by Serratia plymuthica HRO-C48. Plant Dis. 85: 529-534.

Li, A.; Wei, Y.; Sun, Z.; Fan, T. and Zhang, L. (2012). Analysis of bacterial and fungal community structure in replant strawberry rhizosphere soil with denaturing gradient gel electrophoresis. Afr. J. Biotech. 11(49): 10962-10969. 
Neelam,T. and khan, L. (2013). Evaluation of strawberry varieties for their resistance against root- knot nematode, Meloidogyne incognita. Indian J. Nematol. 43(2): 148-151.

Perry, N.R.; Moens, M. and Star L.J. (2009). Root-knot nematodes. Wallingford, CAB International, UK, p 483.

Pinkerton, J. and Finn, C. E. (2005). Responses of strawberry species and cultivars to the root-lesion and northern root-knot nematodes. HortSience 40(1):33-38.

Puntener, W. (1981). Manual for Field Trials in Plant Protection. Agricultural Division, Ciba-Geigy Limited, Basle, Switzerland, 205 pp.

Snedecor, G.W. and Cochran, W.G. (1999). Statistical Methods, $5^{\text {th }}$ ed. Ames (IA): Iowa State Univ. Press; p. 593.

Szczygiel, A. (1981). Trials on susceptibility of strawberry cultivars to the northern root knot nematode, Meloidogyne hapla. Fruit Sci. Rep. 8: 115-119.

Zhang, J.; Pang, H.; Ma, M.; Bu, Y.; Shao, W.; Huang, W.; Ji, Q. and Ya, Y. (2016). An apple fruit fermentation (AFF) treatment improves the composition of the rhizosphere microbial community and growth of strawberry (Fragaria $\times$ ananassa Duch 'Benihoppe') Seedlings. PLoS ONE 11(10): e0164776. https:// doi.org/ 10.1371 / journal.pone.0164776

Yuen, G.; Wang, Y.; Wei, L. and Ji, G. (2016). Evaluation of bacterial biological control agents for control of root-knot nematode disease on tomato. Crop Prot. 84: 8-13. 


\section{الملخص العربى}

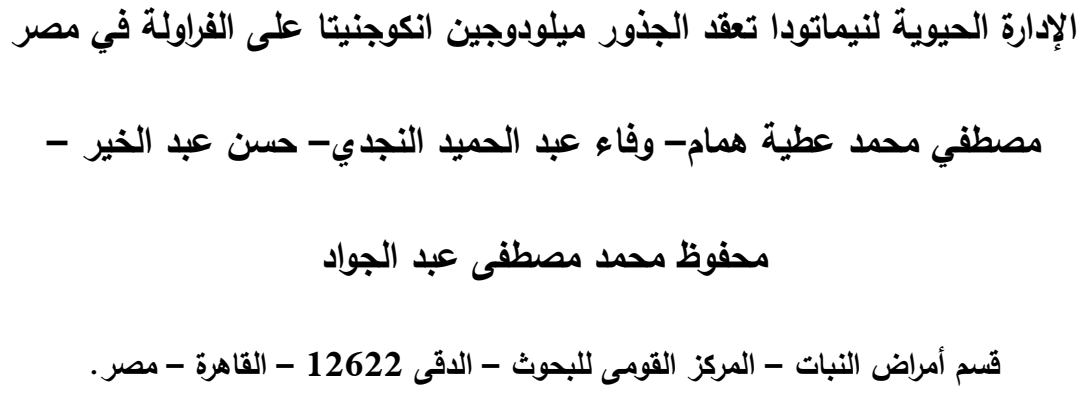

تم دراسة تأثير منتجات تجارية للمكافحة البيولوجية وهي نيماكل، ونيمالس، وميكرونيما، وكنلك الطور اليرقي المعدي من سلالة

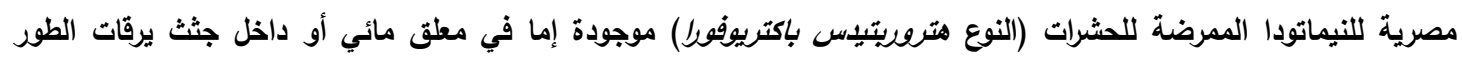

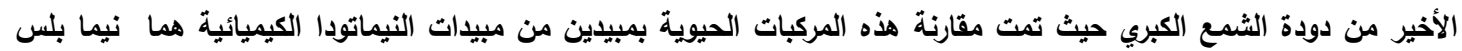

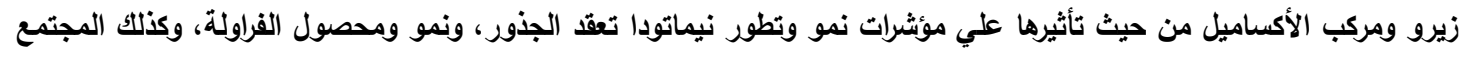
البكتيري الموجود في منطقة جذور الفراولة في تجريتين حقليتين منفصلتين. بعد ستة أثشهر من زراعة الفراولة أحدثت مركبات نيماكل، ونيمالس، وميكرونيما انخفاض بنسبة 30-88٪ في تعداد يرقات الطور اليرقي الثاني من نيماتودا تعقد الجذور المتواجدة بالترية، في حين كان هذا الانخفاض بسبب النيماتودا الممرضة للحشرات 37-64 ٪، أما الانخفاض المتسبب عن مبيدات النيماتودا فكان 64-73\% خفضت المنتجات التجارية يليها النيماتودا الممرضة للحشرات بثكل ملحوظ من أعداد اليرقات، وكتل البيض،

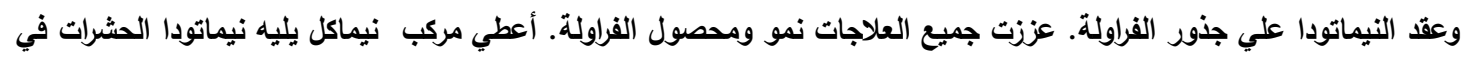
الماء أوداخل الحشرة أفضل إنتاج من محصول الفراولة صنف فستيفال في حين أعطت مركبات نيماكل، ونيمالس، وميكرونيما أفضل إنتاج من محصول الفراولة صنف فرتونا. تم عرض ومناقثة تأثير العلاجات التي تم اختبارها على المجتمع البكتيري الموجود في منطقة جذور الفراولة. الكلمات الدالة: المكافحة الحيوية، النيماتودا الممرضة للحشرات، نيماتودا تعقد الجذور، المجتمع البكتيري الموجود في منطقة الجذور، الفراولة. 